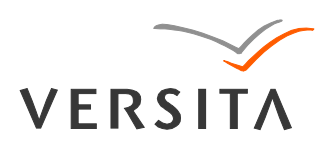

GEOCHRONOMETRIA 40(1) 2013: 77-89

DOI 10.2478/s13386-012-0019-z

Available online at www.springerlink.com

\title{
A DENDROCHRONOLOGICAL ANALYSIS OF PINUS PINEA L. ON THE ITALIAN MID-TYRRHENIAN COAST
}

\author{
SERGIO PIRAINO ${ }^{1}$, SERGIO CAMIZ ${ }^{2}$, ALFREDO DI FILIPPO ${ }^{3}$, \\ GIANLUCA PIOVESAN ${ }^{3}$ and FRANCESCO SPADA ${ }^{4}$ \\ ${ }^{1}$ Laboratorio de Desertificación y Ordenamiento Territorial (LADyOT), IADIZA, CCT-CONICET-Mendoza, Avda. \\ Ruiz Leal s/n, Parque Gral. San Martín, CC 330, PO Box 5500 Mendoza, Argentina. \\ ${ }^{2}$ Dipartimento di Matematica "Guido Castelnuovo", Università degli Studi di Roma "Sapienza", \\ Piazzale Aldo Moro 5, 00185 Roma, Italy \\ ${ }^{3}$ DendrologyLab, DAF, Università degli Studi della Tuscia, Viterbo, Italy \\ ${ }^{4}$ Dipartimento di Biologia Ambientale, Università degli Studi di Roma "Sapienza", \\ Piazzale Aldo Moro 5, 00185 Roma, Italy
}

Received 28 January 2012 Accepted 4 September 2012

\begin{abstract}
In order to assess the response of the radial growth of Pinus pinea $\mathrm{L}$. to climatic variability in Central Italy, dendrochronological and dendroclimatological analyses were carried out on five different populations scattered along the Tyrrhenian coasts of the peninsula. The aim of this study is to contribute to the understanding of the ecological demands of this species, particularly in the study area.

For each site total ring, early-, and late-wood width chronologies were developed.

Multidimensional analyses were performed for the three tree-ring datasets in order to analyze the relations between sites chronologies. Both Principal Component Analyses and hierarchical classifications highlighted an important difference of one site in respect to the other, probably due to site characteristics.

Correlation functions were performed to infer the main climatic factors controlling the radial growth of the species. For a comparative study, we limited our attention to the common interval 1926-2003 (78 years) in which the response of the tree-ring chronologies to climate at both local and regional scale was investigated.

Positive moisture balance in the late spring-summer period of the year of growth is the climatic driver of $P$. pinea radial growth in the study area. Moreover, this study shows how low summer temperatures strongly favor the radial growth of the species.
\end{abstract}

Keywords: Mediterranean, dendroclimatology, tree-ring, early-wood, late-wood, multidimensional analysis, principal component analysis, hierarchical factor classification.

Corresponding author: S. Piraino

e-mail: spiraino@mendoza-conicet.gov.ar

ISSN 1897-1695 (online), 1733-8387 (print)

(C) 2012 Silesian University of Technology, Gliwice, Poland.

All rights reserved. 


\section{INTRODUCTION}

Pinus pinea is a widespread tree in the Mediterranean regions, covering 380,000 ha, 19,000 of which in Italy, mostly located in coastal areas (Moussouris and Regato, 1999), where its forests represent an important environmental and historical value. Large stands have been planted or managed along the coast since antiquity for timber and cone production, and in recent times to prevent erosion of the coastline (Gabbrielli, 1993; Ayrilmis et al., 2009). Nevertheless, natural stands of $P$. pinea are very rare along the Mediterranean coasts, while the bulk of its range is located on the Atlantic side of the Iberian Peninsula. Relic disjunct stands occur far East in Lebanon and Northern Turkey (Trapezun district: see Critchfield and Little, 1966). The few natural stands in Italy grow under Mediterranean climatic conditions, characterized by summer drought and high inter-annual variability of precipitation and temperature (Walter 1973), where summer drought is the crucial factor in limiting plant growth. At the Iberian Peninsula, the widespread stands are influenced by the oceanic climate, with a higher frequency of relatively cool summers; thus, plant growth is not limited by the classic Mediterranean climate constraints. The disjunct pine stands on the slopes of the Lebanon mountains and the Southern coasts of the Black Sea benefit in locations where the local mesoclimate provides more oceanic conditions than the ones provided by the generally drier macroclimate ruling along the Mediterranean coasts (Zohary, 1973; Richardson, 1996), apparently favourable to more xerophilous species of pines ( $P$. halepensis, P. brutia). Hence, we can infer that the species needs cooler and wetter summers for its successful radial growth than the one provided by the Mediterranean type climate (Ashmann 1973).

Tree-ring analysis is a powerful tool for the identification of the most important relations between tree radial growth and climate in the present (Fritts, 1976). In conifers the intra-annual responses of radial growth to local climatic variations have been successfully assessed through the study of the relation between total ring, earlywood (the part of the annual ring formed in the springearly summer period) and late-wood (formed during late summer-autumn period) widths (Kaennel and Schweingruber, 1995) with climatic data (e.g. Campelo et al., 2006; Bogino and Bravo, 2008).

A close relation between radial growth and climatic factors in $P$. pinea has been detected analyzing the influence of climate on radial growth, however only at a local scale (Cherubini, 1993; Akkemik, 2000; Campelo et al., 2006; De Luis et al., 2009). The development of tree-ring networks can provide a more accurate ecological description of trees, and contributes to improve the knowledge of their ecological demands and bio-geographical assessment. Moreover, the analysis of the relation between growth indices and climatic variables at the regional scale can help to predict how the species can behave in a climatically unstable scenario.

Therefore, the objectives of this work are: $i$ ) to develop a tree-ring network for $P$. pinea along the coasts of Central Italy regarding total ring, early-, and late-wood widths, and ii) to study the adaptation of the species to its environmental envelope through the analysis of the effects of climatic patterns on the radial growth at both local and regional scale.

\section{MATERIAL AND METHODS}

\section{Sites description}

The study area is located on the Western coast of Central Italy, between $41.30^{\circ}$ and $43.72^{\circ} \mathrm{N}, 10.31^{\circ}$ and $13.03^{\circ}$ E (Fig. 1). Five different sites were selected: San Rossore, Cecina, Duna Feniglia in Tuscany, and Castelporziano and Circeo in Latium (Table 1). All these sites lie close to the coastline. The stands grow under Mediterranean climatic conditions, locally characterized by a summer drought ranging from one to three months (Fig. 2). In these sites the species grows on sandy soils. The stands of San Rossore, Cecina, and Circeo have been planted on areas which were claimed during the first half of the 20th century. The population of Duna Feniglia is also originated by earlier plantations and grows on Holocene dunes close to a brackish lake. At Castelporziano the pine stands were planted in the 18-19th century on former late-Quaternary dunes, where a previous mixed deciduous-evergreen forest had been destroyed.

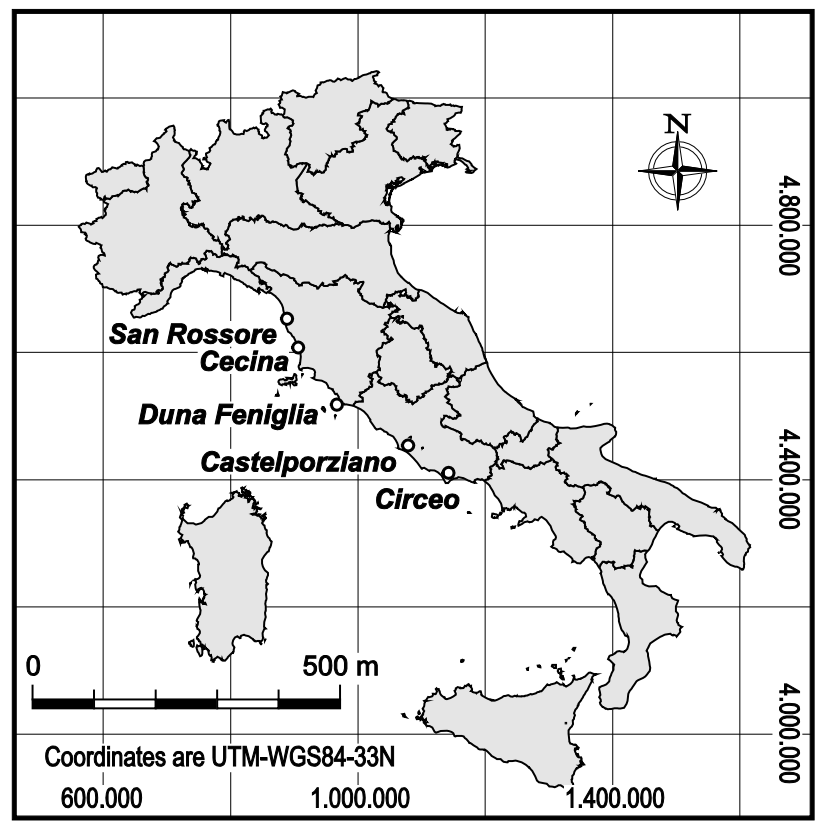

Fig. 1. Geographical location of the studied sites. 
Table 1. Characteristics of the sampled sites. Lat = Latitude, Long = Longitude; Trees = Number of sampled trees per site; $D B H=$ range of the sampled logs diameters at breast height; Time span = time range of the sampled populations.

\begin{tabular}{lccccc}
\hline Site & Lat $\left({ }^{\circ} \mathbf{N}\right)$ & Long $\left({ }^{\circ} \mathrm{E}\right)$ & Trees & DBH $(\mathbf{c m})$ & Time span \\
\hline San Rossore & 43.72 & 10.31 & 19 & $56-82$ & $1861-2003$ \\
Cecina & 43.31 & 10.52 & 17 & $41-57$ & $1851-2003$ \\
Duna Feniglia & 42.44 & 11.22 & 19 & $35-76$ & $1925-2003$ \\
Castelporziano & 41.74 & 12.40 & 21 & $60-76$ & $1897-2003$ \\
Circeo & 41.31 & 13.03 & 31 & $55-84$ & $1878-2004$ \\
\hline
\end{tabular}

At each site, we studied pure stands of this species, with only rare arboreal associates in the understorey, i.e. evergreen (Quercus ilex, Q. suber) and deciduous oaks (Q. pubescens s.l., Q. cerris) and a scanty thicket of sclerophyllous treelets and shrubs of the Mediterranean " $m a$ quis".

\section{Tree-ring chronology}

Tree-ring chronologies were developed from wood samples using standard dendrochronological procedures (Stokes and Smiley, 1968). At each site, 15-20 trees were sampled at breast height (about $1.3 \mathrm{~m}$ from the ground; Fritts, 1976) and one sample per tree was extracted with incremental borers. Additionally, 14 individual series (6 for San Rossore and 8 for Circeo sites) developed by Biondi (1992) were downloaded from the ITRDB web page (The International Tree-Ring Data Bank: http:/www.ncdc.noaa.gov/paleo/treering.html). Wood samples were put on core mounts and surfaced with the use of a scalpel. Tree-ring widths $(T R W)$ were measured in a radial direction, from the bark to the pith to the nearest $0.01 \mathrm{~mm}$ using the sliding stage micrometer CCTRMD and recorded through the CATRAS program (Aniol, 1983 and 1987). Due to the clear distinction between the early to late-wood transition, we also measured early- $(E W W)$ and late-wood $(L W W)$ widths in the same way as the $T R W$ measurements. Each measure was crossdated and checked both visually (via $C A T R A S$ ) and statistically (via COFECHA program; Holmes, 1983). Statistical parameters commonly used in dendrochronology were calculated: 1) the mean sensitivity $(M S)$ which is the mean percent change from each measured yearly ring value to the next; and 2) the first order autocorrelation $(A C 1)$, the correlation of each value in a time series with the value of its predecessor with a time lag of one year (Fritts, 1976). These parameters indicate the sensitivity of the species to environmental factors.

The cross-dated raw series were transformed by removing the age-related trend usually present in the raw ring width measurements by using the program ARSTAN40c (Cook and Krusic, 2006). A negative exponential function was fitted to the raw data and then the original values were subtracted by the fitted ones. Standardized indices used in dendrochronology are often calculated as ratios between the measurement and the fitted
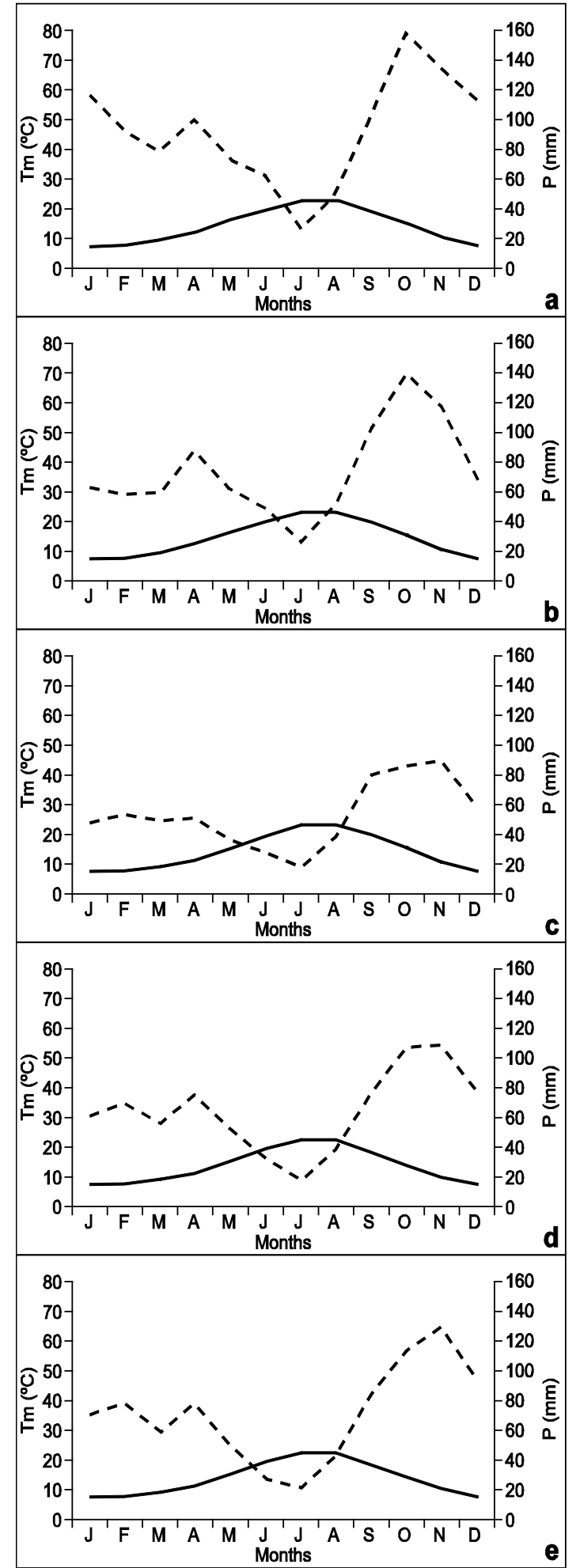

Fig. 2. Ombrothermic diagram of a) Sarzana -San Rossore; b) PisaCecina; c) Grosseto-Duna Feniglia; d) Ciampino -Castelporziano; and e) Latina -Circeo for the period 1971-2000, according to Bagnouls and Gaussen (1953). Data of the Military Air Force - National Centre of Meteorology and Climatology (available at http://clima.meteoam.it/downloads.php). Tm = monthly air temperature; $P=$ monthly total rainfall. Solid line refers to monthly air temperature, dot line to monthly total rainfall. 
curve value. Since ratios can inflate the tree-ring index, the use of residuals was chosen to avoid possible overestimations in the standardization process (Cook and Peters, 1997; Helama et al., 2004).

The Expressed Population Signal (EPS), a measure of how the mean chronology derived from the sampled trees represents a hypothetical infinitely replicated chronology, was used to evaluate the reliability of each chronology (Wigley et al., 1984). In the following analyses, the period 1926-2003 (78 years), common to all chronologies, has been taken into account.

\section{Multidimensional analysis}

Relations between the tree-ring chronologies were explored with both ordination and classification multidimensional analyses (Whittaker, 1973; Tukey, 1977, Camiz et al., 2006). For the ordination, the classical Principal Component Analysis was run (PCA; Orlóci, 1978; Jolliffe, 1986; Legendre and Legendre, 1998). According to the Kaiser-Guttman's rule (Guttman, 1954), we decided to take into account the principal components whose eigenvalues are larger than 1 .

For the classification of the series, we ran the Hierarchical Factor Classification (HFC; Denimal, 2001). At each step, a node is composed by merging two already existing groups and to it $H F C$ associates a factor plane where to represent both aggregated variables and units. Thus, $H F C$ acts simultaneously as both classification and factor analysis tools (Camiz et al., 2006; Camiz and Pillar, 2007). Indeed, at each step, given a node, the associated first principal component represents what the variables of the merging groups have in common, whereas the second one represents the main differences between the groups (Camiz et al., 2006). As the latter is adopted as hierarchy index, its value suggests the cut-point to identify the partitions. Indeed, a value larger than one would mean that the second principal component of a node has the same weight of an original variable, that is to say that the node clusters two nodes whose differences are too large to reasonably gather them. According to both Guttman (1954), Jolliffe (1986), and the practice, we considered questionable to merge groups at fusion levels higher than 0.8 .

For this work, $P C A$ was run through the SPAD package (Lebart et al., 1999) and HFC through Clahfac program (Denimal, 2001).

\section{Climate-growth relation}

The tree radial growth/climate relations were analyzed through correlation functions (Fritts, 1976). The climatic data were extracted from the data set of the project $C L I$ $M A G R I$ assessed according to a grid of $1^{\circ} \times 1^{\circ}$ cells of geographical coordinates covering the whole Italy (Brunetti et al., 2006). A set of 19 climatic monthly timeseries was selected, from May of the year preceding the ring formation to November of the current year of growth. Site standard chronologies were matched against monthly total precipitation $(P)$, monthly mean maximum air temperature (Tmax), and monthly mean minimum air temperature ( $\mathrm{Tmin})$ time-series.

To describe the climatic signal shared by these Tyrrhenian populations, the correlation functions were calculated for the tree-ring, early- and late-wood width chronologies as well as for the three chronologies represented by the first principal components $(P C 1)$ of $P C A$ performed on the three dendrochronological datasets. For the latter analysis, we built a regional series of climatic data, averaging the values for each grid cell. In addition, correlation functions were performed between $\mathrm{PC} 1 \mathrm{~s}$ and monthly Palmer Drought Severity Index (PDSI; Palmer, $1965)$ to analyse the influence of drought at regional scale. The PDSI index takes into account precipitation, evapo-transpiration, and soil moisture conditions, all of which are indicators of drought. PDSI monthly series for the study area were derived from the Dai et al. (2004) $2.5^{\circ} \times 2.5^{\circ}$ gridded data set.

The correlation values were computed and tested for significance with the program DENDROCLIM2002 (Biondi and Waikul, 2004), by applying the bootstrap method (Guiot, 1991).

\section{RESULTS}

\section{Characteristics of the tree-ring network}

107 wood samples were used to build 15 site chronologies, 5 for $T R W, 5$ for $E W W$, and 5 for $L W W$. The populations were of different ages (Table 1), ranging from 79 years at Duna Feniglia to 153 years at Cecina. The mean correlation among trees $(M C)$ ranks from 0.424 (Cecina $L W W, 153$ years) to 0.763 (Castelporziano TRW, 107 years), all at least at 5\% significance level (Table 2). Statistical parameters ( $M S$ and $A C 1$, Table 2) indicate homogeneous values within the 15 chronologies, with the $L W W$ showing the highest values of $M S$ and lowest of $A C 1$. For each site, the $E W W$ is about $70-80 \%$ of the total tree-ring width. Castelporziano, Duna Feniglia and Circeo show the highest percentage of late-wood (Table 2). The EPS for all pre-whitened site chronologies is higher than the critical value of 0.85 on the common period 1926-2003 (Table 2).

\section{Multidimensional analysis}

Three PCAs were run separately on each of the three datasets (TRW, $E W W$ and $L W W$; Fig. 3). It is well known that the most relevant numerical result of $P C A$ is the percentage of inertia as a measure of the importance of a component. In the $T R W$ analysis, the first principal component explains $43.83 \%$ of the total inertia and the second one, not negligible, contributes up to $65.88 \%$. For $E W W$, the first principal component explains $41.42 \%$ and the other adds up to $62.36 \%$; in $L W W$, the first contributes with $40.07 \%$ and the second adds up to $64.59 \%$. Thus, 
Table 2. Statistical parameters of the sampled sites: $M C=$ mean correlation between trees, $M S=$ Mean Sensitivity, $A C 1=$ First order Autocorrelation, Corr $=$ Correlation between site chronology and first principal component; EPS $=$ Expressed Population Signal. \% = Percentage of early-wood and late-wood in the whole ring.

\begin{tabular}{|c|c|c|c|c|c|c|c|c|c|c|c|c|c|c|c|}
\hline \multirow{2}{*}{ Site } & \multicolumn{5}{|c|}{ Total-ring Width } & \multicolumn{5}{|c|}{ Early-wood } & \multicolumn{5}{|c|}{ Late-wood } \\
\hline & $M C$ & MS & $A C 1$ & Corr & $E P S>0.85$ & $M C$ & MS & $A C 1$ & Corr & $\%$ & $M C$ & MS & $A C 1$ & Corr & $\%$ \\
\hline San Rossore & 0.490 & 0.244 & 0.904 & 0.873 & $1894-2003$ & 0.490 & 0.246 & 0.933 & 0.872 & 80 & 0.692 & 0.429 & 0.704 & 0.760 & 20 \\
\hline Cecina & 0.472 & 0.277 & 0.916 & 0.436 & $1892-2003$ & 0.500 & 0.329 & 0.910 & 0.485 & 78 & 0.424 & 0.384 & 0.720 & 0.650 & 22 \\
\hline Duna Feniglia & 0.578 & 0.254 & 0.980 & 0.109 & $1926-2003$ & 0.575 & 0.277 & 0.866 & -0.076 & 72 & 0.611 & 0.354 & 0.835 & 0.484 & 28 \\
\hline Castelporziano & 0.763 & 0.240 & 0.924 & 0.850 & $1901-2003$ & 0.753 & 0.269 & 0.877 & 0.833 & 71 & 0.703 & 0.390 & 0.676 & 0.657 & 29 \\
\hline Circeo & 0.527 & 0.220 & 0.897 & 0.710 & 1878-2004 & 0.509 & 0.233 & 0.866 & 0.613 & 75 & 0.539 & 0.340 & 0.743 & 0.580 & 25 \\
\hline
\end{tabular}
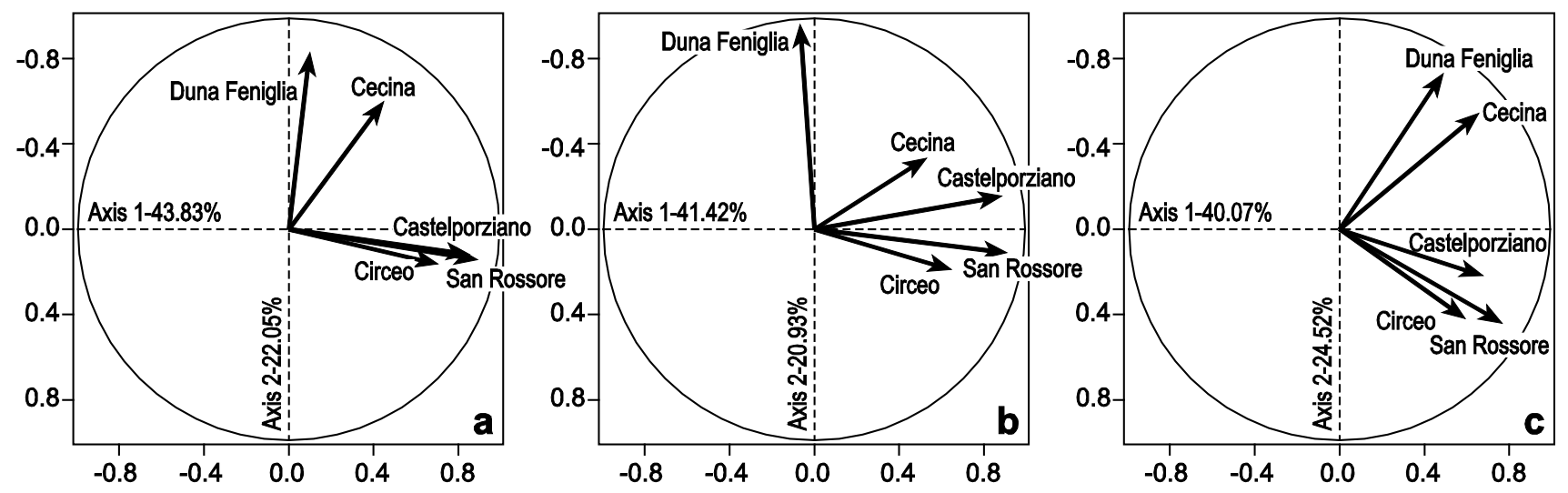

Fig. 3. The pattern of the chronologies on the planes spanned by the first two principal components of PCAs: $a=$ Tree-rings, $b=$ Early-wood, $c=$ Late-wood.

two principal components seem to be important to describe sufficiently well the five chronologies independently from the kind of wood taken into account.

Considering the numerical results of the $H F C$, the fusion level is a measure of the diversity of the groups obtained by cutting the dendrogram at each level: here the $T R W$ chronologies dendrogram (Fig. 4) suggests either two or three classes (with fusion levels 1.09 and 0.83, respectively), depending upon whether to consider Cecina and Duna Feniglia to be clustered or no. The dendrogram of the $E W W$ suggests three groups (1.00 and 0.86, respectively), with Cecina and Duna Feniglia clearly separated, whereas the $L W W$ one shows two groups (1.20) only, with these two chronologies clearly aggregated. The other three chronologies are always clustered together, with Circeo joining the other two at a higher level.

\section{Radial growth-climate relations}

The correlation function analysis performed for the $T R W$ site chronologies indicates that radial growth is almost always positively correlated to the spring-summer moisture (from March to September) of the current year, with the exception of the Duna Feniglia chronology (Fig. 5). Radial growth is also positively influenced by precipitation and negatively by temperatures (that is, the growth is favored by high precipitation and low temperature) of the late

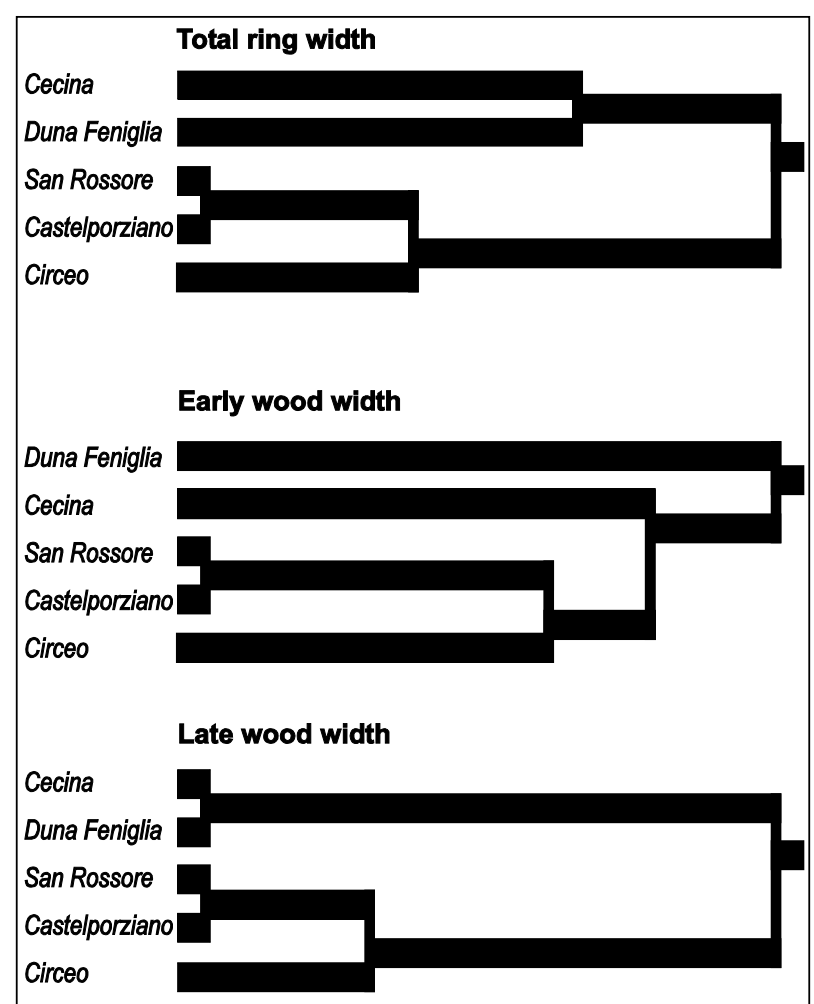

Fig. 4. The dendrograms created by HFC of the chronologies of the whole tree-rings, early-wood and late-wood widths. 


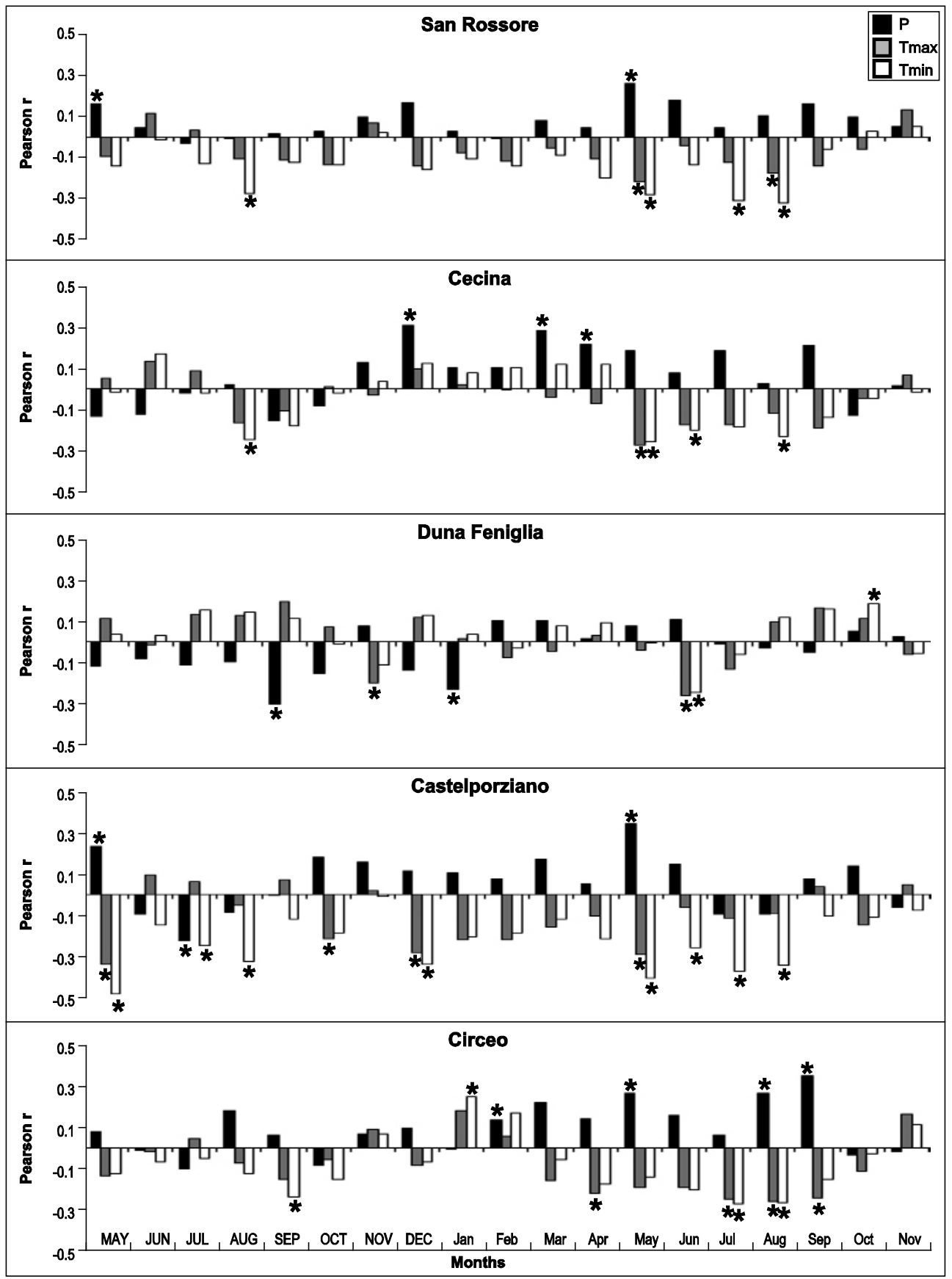

Fig. 5. Correlation functions between standardized total ring width site chronologies and monthly total amount of precipitation $(P=b l a c k$ bars), mean monthly maximum $($ Tmax $=$ gray bars) and minimum temperature $(T \min =$ white bars $)$. Upper case $=$ months of the preceding year. Lower case $=$ months of the current year. The black asterisks indicate months whose correlation is significant at least at $p<0.05$.

autumn-winter period of the previous year, with a special characterization by high precipitation at Cecina and low temperatures at Castelporziano. The correlation function calculated for the $E W W$ site chronologies confirm the results previously reported. Then, the development of the early-wood width is favored, at the site scale, by positive moisture in the spring-summer season (Fig. 6). Again, the Duna Feniglia chronology does not seem to respond clearly to the climatic variability. On the other hand, the analysis of the correlation functions performed for the $L W W$ site chronologies shows that the development of this part of the ring is mainly positively influenced by a late summer-autumn period (from August to November) characterized by a positive moisture balance (i.e. abundant rainfall and low temperatures) (Fig. 7). In addition, at Castelporziano site, the $L W W$ formation is negatively 


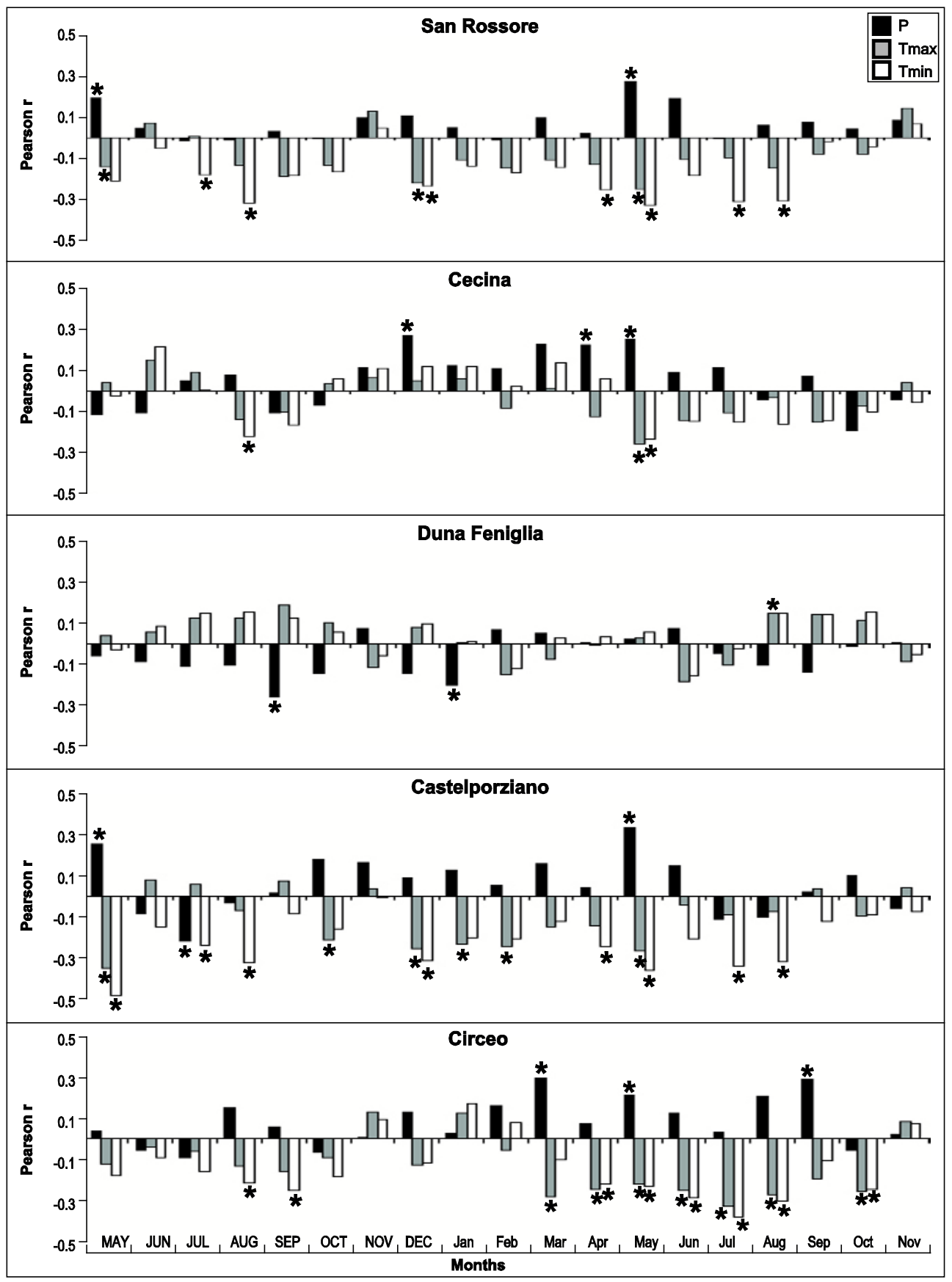

Fig. 6. Correlation functions between standardized early-wood width site chronologies and monthly total amount of precipitation ( $P=$ black bars), mean monthly maximum (Tmax =gray bars) and minimum temperature (Tmin $=$ white bars). Upper case $=$ months of the preceding year. Lower case $=$ months of the current year. The black asterisks indicate months whose correlation is significant at least at $p<0.05$.

influenced by temperatures of the preceding year (May, July, August, October, and December).

The correlation functions performed for the first component $(P C 1)$ of $T R W$ (Fig. 8) confirm the positive influence of precipitations (May and August) and the negative one of temperatures (from May to August) in the late spring-summer period of the current year over radial growth at a regional scale. Negative correlations were found for minimum temperatures of the spring-summer period and December of the previous year, and positive relations for precipitation of May of the previous year. The $T R W$ is also positively influenced by $P D S I$ values of May and June of the previous year, and from October of the previous year to November of the year of growth (Fig. 9). 


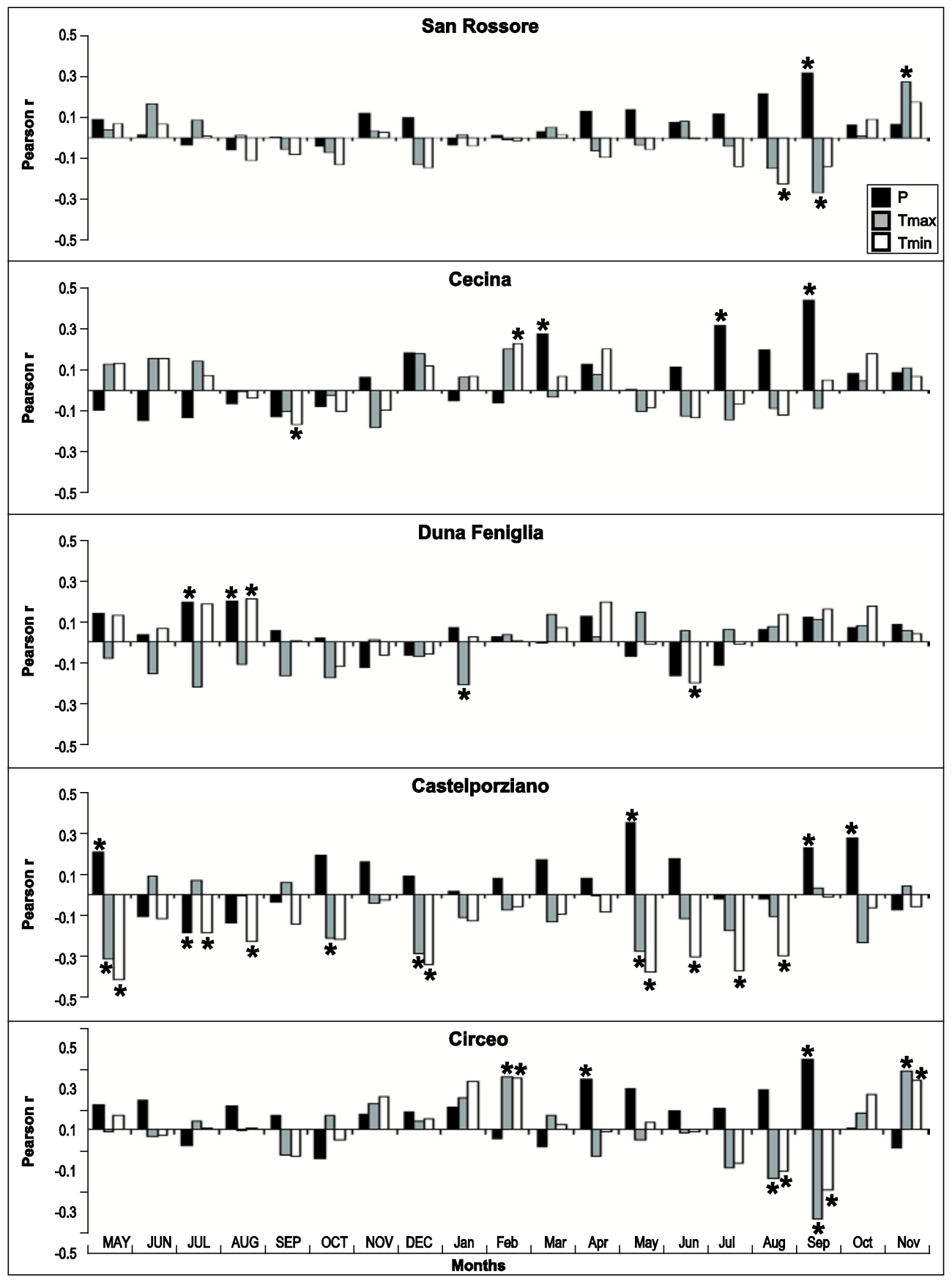

Fig. 7. Correlation functions between standardized late-wood width site chronologies and monthly total amount of precipitation ( $P=$ black bars), mean monthly maximum (Tmax =gray bars) and minimum temperature (Tmin $=$ white bars). Upper case $=$ months of the preceding year. Lower case $=$ months of the current year. The black asterisks indicate months whose correlation is significant at least at $p<0.05$.

Considering correlations functions performed for the $E W W$ and $L W W P C 1 s$ (Fig. 8), the results seem to confirm those of the whole ring. At a regional scale, the growth of the $E W W$ is positively influenced by the amount of precipitation in May, and negatively by the temperatures from April to September of the current year. The positive moisture balance in May of the preceding year favors the development of $E W W$, while both the summer minimum temperatures and the December temperatures of the previous year negatively influence the formation of this part of the ring. Moreover, $E W W$ shows the same relations as $T R W$ with $P D S I$ (positive correlations with $P D S I$ values of May and June of the previous year and with the values from October of the previous year to November of the year of growth; Fig. 9). 


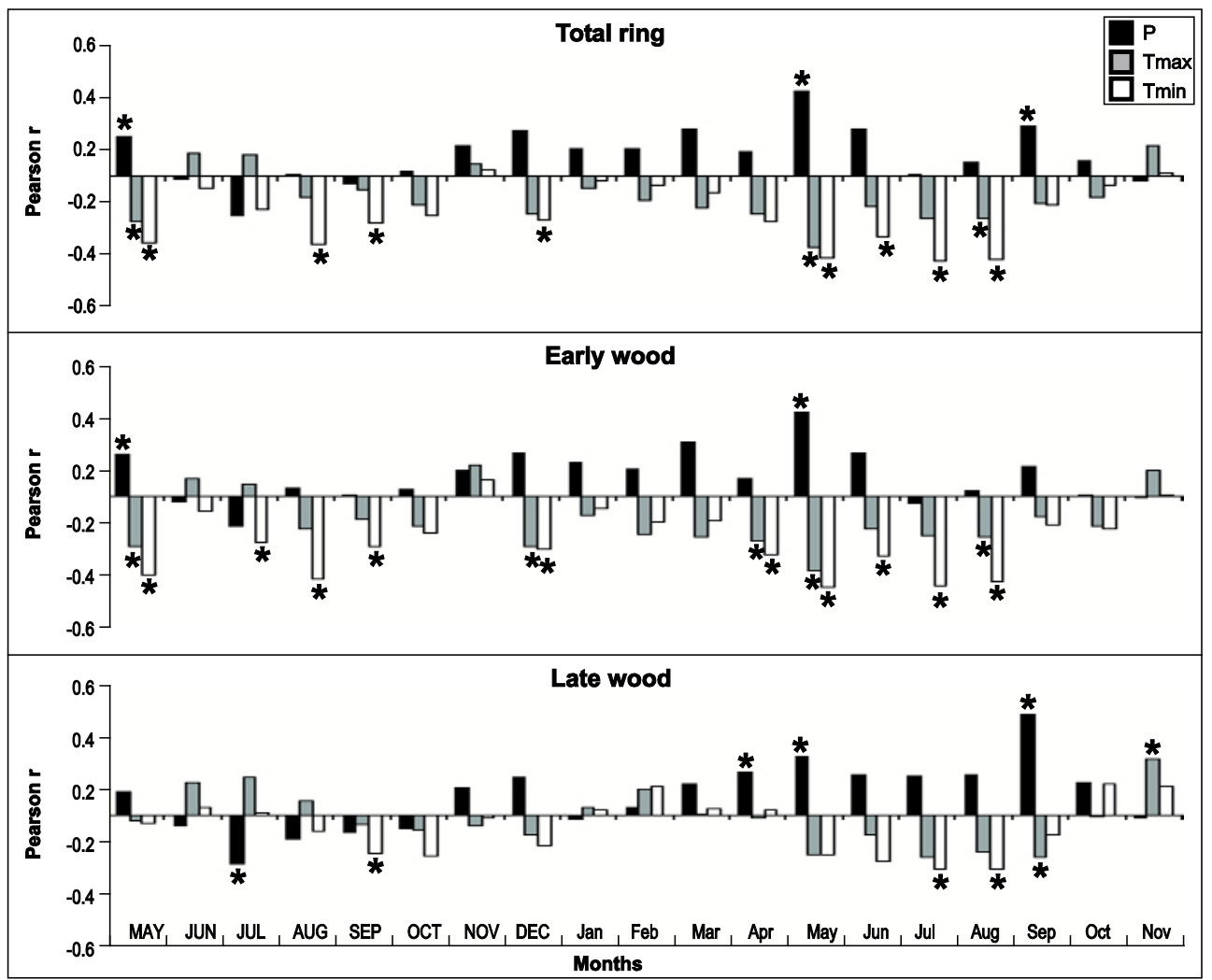

Fig. 8. Correlation functions between PC1 of the three PCAs on sites chronologies for total ring, early-, and late-wood widths, and monthly total amount of precipitation $(P=$ black bars), mean monthly maximum (Tmax =gray bars) and minimum temperature $($ Tmin $=$ white bars). Upper case $=$ months of the preceding year. Lower case $=$ months of the current year. The black asterisks indicate months whose correlation is significant at least at $p<0.05$.

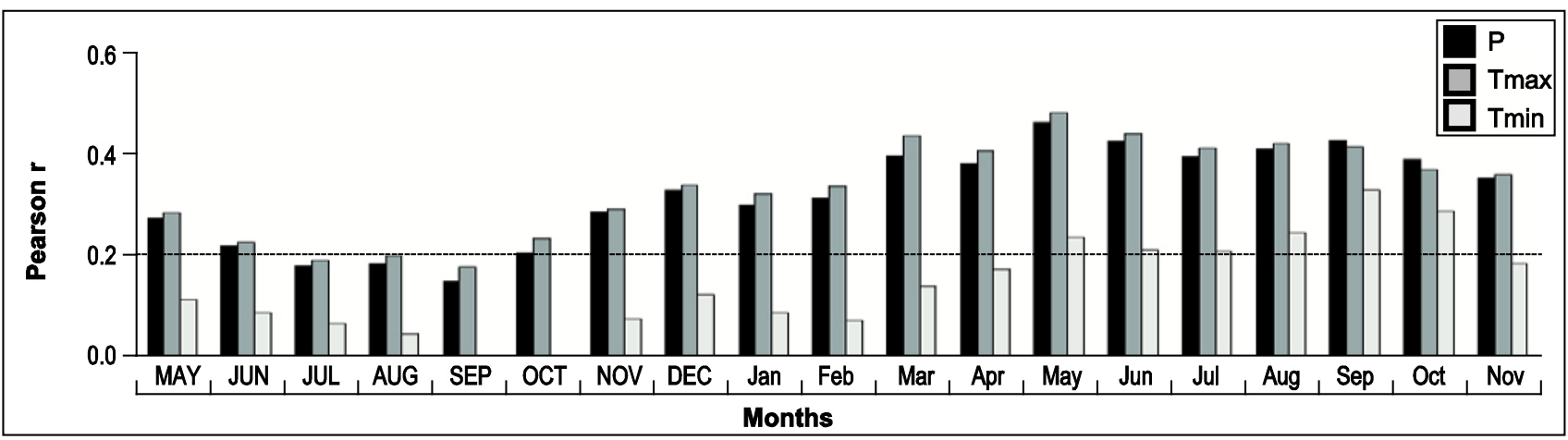

Fig. 9. Correlation functions between PC1 of the three PCAs on sites chronologies for total ring, early-, and late-wood widths, and mean monthly values of PDSI. Upper case $=$ months of the preceding year. Lower case $=$ months of the current year. The dashed line represents the $95 \%$ confidence limit.

The correlation functions performed for the $L W W$ $P C 1$ show how the formation of this part of the ring is positively influenced by both spring (April-May) and September precipitations of the current year, with the latter highly correlated to the late-wood development. $L W W$ is negatively correlated to summer (June-July) minimum temperatures. Moreover we detected a negative correlation between $L W W$ growth and precipitation in
July and minimum temperatures in September of the preceding year and a positive relation with maximum temperature of November of the current year. Finally PDSI in the May-October period of the year of growth positively influences $L W W$, with the highest correlation values for the PDSI index in September and October (Fig. 9). 


\section{DISCUSSION AND CONCLUSION}

Statistical parameters ( $M S$ and $A C 1)$ corresponding to the five different sites do not indicate significant differences according to the spatial distribution. Therefore, these parameters do not seem to reflect any particular ecological or climatic gradient. They rather suggest a uniform sensitivity of these pine populations to the environment. On the other hand, the $M S$ and $A C l$ values of $L W W$ suggest that this part of the annual ring is apparently more sensitive to environmental constrains.

In each site and for each tree-ring parameter, a high percentage of inertia explained by $M C$ may be considered as a signal shared by all individuals, probably as a consequence of the influence of a dominant environmental (climatic) factor over radial growth. EPS, always higher than the 0.85 threshold for the time span in common to all sampled trees in each site (Table 2), allows to assume that these chronologies can well describe hypothetical and infinite $P$. pinea populations at each sampling site (Wigley et al., 1984).

Two sites, Castelporziano and Duna Feniglia, show the highest percentage of late-wood, followed by the Circeo site. These higher values are statistically significant (one-way ANOVA: $\mathrm{DF}=3, \mathrm{~F}=13.54, p=0.0348$ ), and may reflect higher water stress conditions. This can be also inferred by the analysis in Fig. 2, which shows how these three sites are characterized by three months of drought conditions during the summer period. Indeed, it is well known that a higher late-wood/early-wood ratio can be a strategy of conifers growth in dry climate (Domec and Gartner, 2002).

The multidimensional analyses show that all chronologies, except Duna Feniglia, contribute to the first axis: more weakly Cecina and more strongly the other three ones. This suggests the existence of a common signal for four chronologies, namely San Rossore, Cecina, Castelporziano and Circeo. Indeed, in all analyses, Cecina contributes (with different weights) to the second axes as well, axes to which Duna Feniglia contributes most. This reflects the non-significant correlations of Duna Feniglia with the other chronologies for both the TRW and the $E W W$ and significant with Cecina for the $L W W$. This behavior of Duna Feniglia is also reflected in a lack of signals connected to climatic influence (with the exception of a negative influence of July temperatures over annual radial growth). The reason can be that this population was planted in 1911 on a narrow sandy strip of dunes separating the sea from a lagoon with brackish water (Gabbrielli, 1993). The lagoon itself is located on a flat isthmus connecting the promontory of Monte Argentario (632 m.a.s.l.) with the Tuscanian coast. The water-table is apparently affected by salty water on both sides of this sandy narrow strip. The action of salts on roots and on the absorption of phreatic water is known to be detrimental to the growth of $P$. pinea, especially during periods of lower precipitation (Teobaldelli et al., 2004). Consequently, the location of Duna Feniglia might bias the relation with the climatic parameters that influence the other sites. Moreover, since the isthmus is exposed to both Northern and Southern quadrants dominating winds (Bellarosa et al., 1996), the negative effects of enhanced evapotranspiration can be suggested in the interpretation of the observed pattern.

From a physiological viewpoint, $P$. pinea is known to reduce photosynthesis when water stress occurs, a mechanism that has been observed in this species during summer and early autumn, and does not show any summer quiescence (Liphschitz et al., 1984; Awada et al., 2003; Teobaldelli et al., 2004). It can therefore be considered as a drought-tolerant Mediterranean species that continues its growth, albeit reduced, during the dry season (Specht, 1981; de Lillis and Fontanella, 1992).

Our analysis shows that the radial growth of $P$. pinea (TRW, $E W W$ and $L W W$ ) along the western coast of middle Italy is mainly favored by positive moisture of the late spring-summer period of the current year and, more slightly, negatively influenced by the previous year winter temperatures. During the spring-summer period (March to September of the year of growth), the cambium activity takes place (Liphschitz et al., 1984). Then, the tree is highly dependent upon the amount of water stored in the soil for the construction of the ring (Campelo et al., 2006).

The April-May period represents a crucial moment for the radial growth of the species. The negative relation found for the $E W W P C 1$ with April temperatures, associated with the positive relation with precipitation for the $L W W P C 1$ in the same month, may be explained considering that for this species the cambial activity begins during March (Liphschitz et al., 1984). Then, positive moisture favors the development of the ring at the beginning of the growing season. Radial growth is also favored by the positive moisture balance during May of the year of growth, outlined by the correlation functions performed for both site chronologies and PCl of $T R W$ and $E W W$. This signal is strengthened by the positive correlation found for precipitation and $L W W P C 1$ chronology. The same climate-radial growth signal was reported for the species in Turkey and in the Iberian Peninsula (Akkemik, 2000; Campelo et al., 2006; De Luis et al., 2009).

These results suggest severe constraints of summer drought on the species growth. Indeed, drought restrains some physiological processes that take place during this period, as shoot elongation, bud lengthening, cone development and phloem growth (Liphschitz et al., 1984; Mutke et al., 2003). Furthermore, drought conditions during late spring can provoke xylem embolism (Oliveras et al., 2003). Thus, in this period the tree physiology and growth are strictly dependent on climatic variability.

The $L W W$ formation is negatively influenced at a regional scale by high precipitation of July of the previous year. Since low precipitation can cause the cone abortion 
(Mutke et al., 2005), it may be hypothesized that the carbohydrates not used in the cone development during the previous year will be used in the $L W W$ formation during the year of growth.

High maximum temperatures during November of the current year favor the construction of the $L W W$, suggesting that in Mediterranean regions photosynthesis can take place also during a mild autumn, by producing carbohydrates necessary for the ring formation (Kozlowski et al., 1991). Low December temperatures of the previous year favor both $T R W$ and $E W W$ formation, probably reducing the evapo-transpiration processes that can negatively influence the recharge of the soil water-table (Campelo et al., 2006).

The analysis of correlation functions between radial growth and PDSI values confirms the importance of a positive moisture balance during the growing season for $P$. pinea radial growth, previously reported for the combined influence of precipitation and temperatures. PDSI index takes into account precipitation, temperature, evapo-transpiration and soil moisture. For this reason, it is considered a key indicator of drought conditions (Cook and Jacoby Jr, 1977; Meko et al., 1993).

Several works have analysed the dendroclimatology of different Mediterranean Pinus species. In southern Italy and in France, bioclimatic models show that the annual radial growth of $P$. halepensis is mainly sensitive to soil water availability during the growing season (Attolini et al., 1990; Rathgeber et al., 2005). In Greece, for the same species it was found that $T R W$ is enhanced by a high amount of winter and spring precipitations and negatively influenced by high temperatures of the spring months (Papadopoulos et al., 2009). In the Iberian Peninsula, the growth of $P$. halepensis is mainly favoured by abundant precipitations of the spring season (Olivar et al., 2012). In the stands of central Spain, the annual radial growth of $P$. pinaster is favoured by high precipitations in the spring-early summer season (Bogino and Bravo, 2008). The $T R W$ of $P$. pinaster is enhanced by a positive moisture balance during spring on the coasts of northwestern Portugal (Vieira et al., 2009). In southern Spain, the radial growth of $P$. halepensis is positively influenced mainly by the amount of precipitation during the springearly summer season (De Luis et al., 2009).

Regarding $P$. pinea, the species has been previously studied using dendroclimatological methods in the two core areas of its natural range in the Mediterranean Regions (Akkemik, 2000; Campelo et al., 2006; De Luis et al., 2009). In Turkey, only the precipitation regime influences the radial growth at a significant level, since the development of the $T R W$ is positively influenced by the rainfall amount in the spring-summer period (May, June and August) of the current year (Akkemik, 2000). In southern Portugal, the winter precipitations of the preceding year and in May and June of the year of growth positively influence both $T R W$ and $E W W$, while the amount of precipitation in October positively influences the $L W W$ development. Concerning the temperature effect, $T R W$ exhibits a positive response to high temperature in the previous December, whereas the high temperatures in August have a negative effect on the $L W W$ formation (Campelo et al., 2006). In the semiarid coastal area of southern Spain, the amount of precipitation in the growing season (March trough September) positively influences the annual radial growth of the species, while high March temperatures negatively influence $T R W$ (De Luis et al., 2009).

Summarizing, the previously reported dendroclimatological analyses indicate that the positive moisture balance in the spring season is the dominant climatic factor favouring the radial growth of Pinus spp. in the Mediterranean regions. This is true as well for $P$. pinea at both the eastern and western districts of its natural range. Furthermore, this species seems to present also a strong dependence on summer climatic conditions, since abundant rainfalls and low temperatures enhance the development of the ring width.

Our study indicates that the positive moisture balance in late spring-summer of the year of growth is the crucial climatic driver that enhances the radial growth of $P$. pinea in the coastline populations in the mid-Tyrrhenian area. This analysis also shows how temperature too influences the radial growth of the species in the study areas, since low temperatures during the growing season favor the ring-growth. Our results add new information about the role of climatic variability over the radial growth of the species, suggesting that $P$. pinea seems to exhibit some differences in the response to the Mediterranean climatic constraints compared to other Mediterranean pine species such as $P$. halepensis. Indeed, the radial growth of the species apparently follows the pattern of a colder and wetter climate than the one ruling the Mediterranean region (Liphschitz et al., 1984).

This information becomes particularly relevant considering that all over the Mediterranean regions, while annual precipitation is at present decreasing, temperature is increasing (Giorgi, 2006; IPCC WG I, 2007). Since some analyses show an ongoing increase also in winter temperatures (García-Herrera et al., 2007), TRW and $E W W$ formation might be severely affected. The magnitude of this climate shifts is exemplified by an increase of the daily temperature in a range of $0.56{ }^{\circ} \mathrm{C}$ during the period 1961-2004 and by a decreasing trend of monthly precipitation over the last 140 years, mainly related to the spring season (Toreti and Desiato, 2008; Brunetti et al., 2006).

A decrease in precipitation along with more severe evapo-transpiration processes will probably reduce the summer soil moisture in the whole Mediterranean area (Lavee et al., 1998). All these events might therefore turn detrimental for the radial growth of the species, inducing a reduction of natural and artificial populations across most of its present range. 


\section{ACKNOWLEDGEMENT}

The manuscript greatly benefited from the comments of two anonymous reviewers. Special thanks are due to Dr. Maurizio Maugeri (Università degli Studi di Milano) that supplied the climate data used in this paper. Thanks are also addressed to the Authorities of the Nature Reserves that allowed the sampling in their own areas.

Sergio Piraino is fully indebted to Prof. Fidel Roig (IANIGLA-CONICET) for his help, ideas and encouragement during the development of this article, and to Dr. François Pujos (IANIGLA-CONICET) for his suggestions about an earlier version of this manuscript.

Rafael Bottero (IANIGLA-CONICET) is warmly thanked for his help in the drawing of figures.

Sergio Camiz has been granted by the bilateral agreement between Universidad de Cuyo (Mendoza, Argentina) and Sapienza Università di Roma, as Italian scientific head, and by the Scientific Aggregate of Italian Embassy in Buenos Aires. All institutions are gratefully acknowledged.

\section{REFERENCES}

Akkemik U, 2000. Dendroclimatology of Umbrella pine (Pinus pinea L.) in Istanbul, Turkey. Tree-Ring Bullettin 56:17-20.

Aniol RW, 1983. Tree-ring analysis using CATRAS. Dendrochronologia 1: 45-53.

Aniol RW, 1987. A new device for computer assisted measurement of tree-ring widths. Dendrochronologia 5:135-141.

Ashmann H, 1973. Distribution and Peculiarity of Mediterranean Ecosystems. In Mediterranean Type Ecosystems - Origin and Structure, di Castri F. and Mooney H.A., eds, Berlin, Springer: 11-19.

Attolini MR, Calvani F, Galli M, Nanni T, Ruggiero L, Schaer E and Zuanni F, 1990. The relationship between climatic variables and wood structure in Pinus halepensis Mill. Theoretical and Applied Climatology 41: 121-127, DOI 10.1007/BF00866435.

Awada T, Radoglou K, Fotelli MN and Constantinidou HIA, 2003. Ecophysiology of seedlings of three Mediterranean pine species in contrasting light regimes. Tree Physiology 23(1): 33-41, DOI 10.1093/treephys/23.1.33.

Ayrilmis N, Buyuksari U, Avci E and Koc E, 2009. Utilization of pine (Pinus pinea L.) cone in manufacture of wood based composite. Forest Ecology and Management 259(1): 65-70, DOI 10.1016/j.foreco.2009.09.043.

Bagnouls F and Gaussen H, 1953. Saison sèche et indice xérothermique. Bulletin de la Société d'Histoire Naturelle de Toulouse 88: 193240.

Bellarosa R, Codipietro P, Piovesan G and Schirone B, 1996. Degradation, rehabilitation and sustainable management of a dunal ecosystem in central Italy. Land Degradation \& Development 7(4): 297311, DOI 10.1002/(SICI)1099-145X(199612)7:4<297::AIDLDR235>3.0.CO;2-M.

Biondi F, 1992. Development of a tree-ring network for the Italian Peninsula. Tree-Ring Bullettin 52: 15-29.

Biondi F and Waikul K, 2004. DENDROCLIM2002: a C++ program for statistical calibration of climate signals in tree-ring chronologies. Computers \& Geosciences 30(3): 303-311, DOI 10.1016/j.cageo.2003.11.004

Bogino SM and Bravo F, 2008. Growth response of Pinus pinaster Ait. to climatic variables in central Spanish forests. Annals of Forest Science 65(5): 506. DOI 10.1051/forest:2008025.

Brunetti M, Maugeri M, Monti F and Nanni T, 2006. Temperature and precipitation variability in Italy in the last two centuries from ho- mogenized instrumental time series. International Journal of Climatology 26(3): 345-381, DOI 10.1002/joc.1251.

Camiz S, Denimal JJ and Pillar VDP, 2006. Hierarchical Factor Classification of Variables in Ecology. Community Ecology 7(2): 165179, DOI 10.1556/ComEc.7.2006.2.4.

Camiz S and Pillar VDP, 2007. Comparison of Single and Complete Linkage Clustering with the Hierarchical Factor Classification of Variables. Community Ecology 8(1): 25-30, DOI 10.1556/ComEc.8.2007.1.4.

Campelo F, Nabais C, Freitas H and Gutiérrez E, 2006. Climatic significance of tree-ring width and intra-annual density fluctuations in Pinus pinea from a dry Mediterranean area in Portugal. Annals of Forest Science 64(2): 229-238, DOI 10.1051/forest:2006107.

Cherubini P, 1993. Studio dendroecologico su Pinus Pinea L. in due differenti stazioni sulla costa mediterranea in Toscana (Italia). Dendrochronologia 11: 87-99.

Cook ER and Jacoby GC Jr, 1977. Tree-ring-drought relationships in the Hudson Valley, New York. Science 198: 399-401, DOI 10.1126/science.198.4315.399

Cook ER and Peters K, 1997. Calculating unbiased tree-ring indices for the study of climatic and environmental change. The Holocene 7(3): 361-370, DOI 10.1177/095968369700700314.

Cook ER and Krusic PJ, 2006. Program ARSTAN 40c. Tree-ring Laboratory, Lamont-Doherty Earth Observatory, Palisades, NY.

Critchfield WB and Little EL, 1966. Geographic distribution of the pines of the world. U.S.D.A. Forest Service Miscellaneous Publication 991

Dai A, Trenberth KE and Qian T, 2004. A global dataset of Palmer drought severity index for 1870-2002: relationship with soil moisture and effects of surface warming. Journal of Hydrometeorology 5: 1117-1130, DOI 10.1175/JHM-386.1.

de Lillis M and Fontanella A, 1992. Comparative phenology and growth in different species of the Mediterranean maquis of central Italy. Vegetatio 99-100: 83-96.

De Luis M, Novak K, Cufar K and Raventós J, 2009. Size mediated climate-growth relationships in Pinus halepensis and Pinus pinea. Trees - Structure and Function 23(5): 1065-1073, DOI 10.1007/s00468-009-0349-5.

Denimal JJ, 2001. Hierarchical Factorial Analysis, Actes du 10th International Symposium on Applied Stochastic Models and Data Analysis, Compiègne, 12-15 Juin 2001.

Domec JC and Gartner BL, 2002. How do water transport and water storage differ in coniferous earlywood and latewood? Journal of Experimental Botany 53(379): 2369-2379, DOI 10.1093/jxb/erf100.

Fritts HC, 1976. Tree Rings and Climate. Academic Press. London, UK. $576 \mathrm{pp}$.

Gabbrielli A, 1993. Origine delle pinete litoranee in Toscana. (Origin of coastal pine forests in Tuscany) Conference Proceedings: Salvaguardia delle pinete litoranee (Preservation of coastal pine forests), Grosseto, Italy, 21-22 October 1993, 13-20.

García-Herrera R, Luterbacher J, Lionello P, González-Rouco F, Ribera P, Rodo X, Kull C and Zerefos C, 2007. Reconstruction of past Mediterranean climate. EOS, 88(9): 111, DOI 10.1029/2007EO090010.

Giorgi F, 2006. Climate change hot-spots. Geophysical Research Letters 33: L08707, DOI 10.1029/2006GL025734.

Guiot J, 1991. The bootstrapped response function. Tree-Ring Bullettin 51: 39-41

Guttman L, 1954. Some necessary conditions for common factor analysis. Psychometrika 19: 149-162, DOI 10.1007/BF02289162.

Helama S, Lindholm M, Timonen M and Eronen M, 2004. Detection of climate signal in dendrochronological data analysis: a comparison of tree-ring standardization methods. Theoretical and Applied Climatology 79(3-4): 239-254, DOI 10.1007/s00704-004-0077-0.

Holmes R, 1983. Computer-assisted quality control in tree-ring dating and measurement. Tree-Ring Bullettin 43:69-75.

Jolliffe IT, 1986. Principal Components Analysis, Berlin, Springer.

Kaennel M and Schweingruber FH, 1995. Multilingual glossary of dendrochronology. Terms and definitions in English, German, 
French, Spanish, Italian, Portuguese and Russian. Bern: Paul Haupt Verlag.

Kozlowski TT, Kramer PJ and Pallardy SG, 1991. The physiological ecology of woody plants, Academic Press, New York.

IPCC WG I, 2007. Climate Change 2007: The Physical Science Basis. Contribution of Working Group I. In: Solomon S, Qin D, Manning M, Chen Z, Marquis M, Averyt KB, Tignor M, Miller HL, eds, Fourth Assessment Report of the Intergovernmental Panel on Climate Change. Cambridge University Press, Cambridge.

Lavee H, Imeson AC and Sarah P, 1998. The impact of climate change on geomorphology and desertification along a Mediterranean - arid transect. Land Degradation and Develpopment. 9(5): 407-422, DOI $\quad 10.1002 /(\mathrm{SICI}) 1099-145 X(199809 / 10) 9: 5<407:: A I D-$ LDR302>3.0.CO;2-6.

Lebart L, Morineau A, Lambert T and Pleuvret P, 1999. SPAD Système Pour l'Analyse des Données, version 5.5, Paris, CISIACERESTA.

Legendre P and Legendre L, 1998. Numerical Ecology, $2^{\text {nd }}$ Ed., Amsterdam, Elsevier.

Liphschitz N, Lev-Yadun S, Rosen E and Waisel Y, 1984. The annual rhythm of activity of the lateral meristems (cambium and phellogen) in Pinus halepensis Mill. and Pinus pinea L., IAWA Bulletin 5: 263-274.

Meko D, Cook ER, Stahle DW, Stockton CW and Hughes MK, 1993. Spatial patterns of tree-growth anomalies in the United States and southeastern Canada. Journal of Climate 6: 1773-1786, DOI 10.1175/1520-0442(1993)006<1773:SPOTGA > 2.0.CO;2.

Moussouris Y and Regato P, 1999. Forest harvest: an overview of non timber forest products in the Mediterranean Region. WWF Mediterranean Programme, Rome. http://www.fao.org/docrep/x5593e/x5593e00.htm

Mutke S, Gordo J, Climent J and Gil L, 2003. Shoot growth and phenology modeling of grafted Stone pine (Pinus pinea L.) in inner Spain. Annals of Forest Science 60: 527-537.

Mutke S, Gordo J and Gil L, 2005. Variability of Mediterranean Stone pine cone production: Yield loss as response to climate change. Agricultural and Forest Meteorology 132(3-4): 263-272, DOI 10.1016/j.agrformet.2005.08.002.

Olivar J, Bogino S, Spiecker H and Bravo F, 2012. Climate impact on growth dynamic and intra-annual density fluctuations in Aleppo pine (Pinus halepensis) trees of different crown classes. Dendrochronologia 30(1): 35-47, DOI 10.1016/j.dendro.2011.06.001.

Oliveras I, Martínez-Vilalta J, Jimenez-Ortiz T, Lledó MJ, Escarré A and Piñol J, 2003. Hydraulic properties of Pinus halepensis, Pinus pinea and Tetraclinis articulata in a dune ecosystem of Eastern Spain. Plant Ecology 169(1): 131-141, DOI
10.1023/A:1026223516580.

Orlóci L, 1978. Multivariate Analysis in Vegetation Research, The Hague, Junk.

Palmer JG, 1965. Meteorological drought. U.S. Department of Commerce, Washington, D.C

Papadopoulos AM, Tolica K, Pantera A and Maheras P, 2009. Investigation of the annual variability of the Aleppo pine tree-ring width: the relationship with the climatic conditions in the Attica basin. Global Nest Journal 11: 583-592.

Rathgeber C, Misson L, Nicault A and Guiot J, 2005. Bioclimatic model of tree radial growth: application to French Mediterranean Aleppo pine forests. Trees - Structure and Function 19(2): 162-176, DOI 10.1007/s00468-004-0378-z.

Richardson DM, 1996. Ecology and Biogeography of Pinus. Cambridge University Press. Capetown. 527 pp.

Specht RL, 1981. Primary production in Mediterranean climate ecosystems regenerating after fire. In Mediterraneantype Shrublands, di Castri F., Goodall DW and Specht RL, eds, pp. 257-267. Ecosystems of the world 11, Elsevier Scientific Publishing Company, Amsterdam, The Netherlands.

Stokes M and Smiley T, 1968. An introduction to tree-ring dating. The University of Chicago Press, Chicago. 73 pp.

Teobaldelli M, Mencuccini M and Piussi P, 2004. Water table salinity, rainfall and water use by umbrella pine trees (Pinus pinea L.) Plant Ecology 171(1-2): 23-33, DOI 10.1023/B:VEGE.0000029384.40192.cc.

Toreti A and Desiato F, 2008. Temperature trend over Italy from 1961 to 2004. Theoretical and Applied Climatology 91(1-4): 51-58, DOI 10.1007/s00704-006-0289-6.

Tukey JW, 1977. Exploratory Data Analysis. Reading (Mass): AddisonWesley.

Walter H, 1973. Die Vegetation der Erde in ökophysiologischer Betrachtung. Jena, Fischer 3 vol 1.

Whittaker RH (Ed.), 1973. Handbook of Vegetation Science. V Ordination and classification of vegetation. Junk, The Hague.

Vieira J, Campelo F and Nabais C, 2009. Age-dependent responses of tree-ring growth and intra-annual density fluctuations of Pinus pinaster to Mediterranean climate. Trees - Structure and Function 23(2): 257-265, DOI 10.1007/s00468-008-0273-0.

Wigley TML, Briffa KR and Jones PD, 1984. On the average value of correlated time series, with applications in dendroclimatology and hydrometeorology. Journal of Climate and Applied Meteorology $23(2): \quad 201-213, \quad$ DOI
$0450(1984) 023<0201:$ OTAVOC $>2.0 . C O ; 2$.

Zohary, 1973. Geobotanical foundations of the Middle East. Gustav Fischer, Stuttgart. 